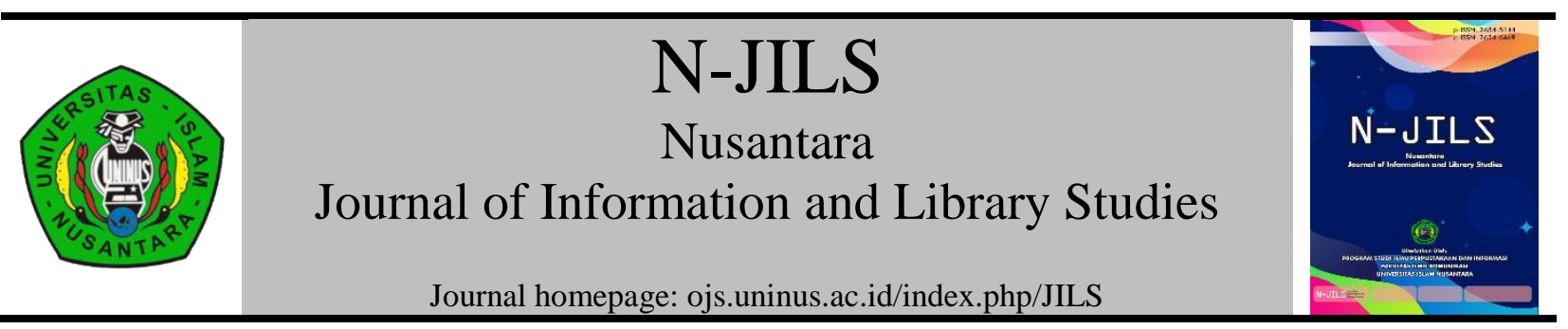

\title{
Hubungan Penyebaran Informasi Pendidikan Seks Dengan Perilaku Orang Tua Di Desa Banjurpassar
}

\section{Relationship Of Dissemination Of Sex Education Information With Parental Behavior At Desa Banjurpassar}

\author{
Diana Rizki Pratiwi ${ }^{1}$ dan Yunus Winoto ${ }^{2}$ \\ 1,2, Program Studi Perpustakaan dan Sains Informasi Universitas Padjadjaran \\ email: ${ }_{1}^{1}$ diana16006@unpad.ac.id, ${ }^{2}$ yunus.winoto@unpad.ac.id
}

\begin{tabular}{ll}
\hline ARTICLE INFO & ABSTRACT \\
\cline { 2 - 3 } Article history & This study aims to determine the relationship of the spread of sex \\
Received [May 2020] & education information with the behavior of parents in explaining \\
Revised [June 2020] & about sex in adolescents. The variables in this study consisted of \\
Accepted [June 2020] & independent variables, namely the dissemination of information \\
Available Online [June 2020] & which includes aspects of communicators, messages and media and \\
the dependent variable, namely the behavior of parents in \\
explaining sex education. The location of the study was conducted \\
in Banjurpassar Village which is one of the village areas in the \\
coastal area of Kebumen Regency. The approach used in this study \\
uses a quantitative approach to the type of correlation research. \\
The population in this study are parents who participated in \\
counseling about sex education provided by the District Health \\
Office, Kebumen. As for the technique of sampling, it uses simple \\
random sampling technique. The data collection techniques are \\
carried out through questionnaires, interviews, observations and \\
through library studies. As for the analysis of data using descriptive \\
statistical analysis and inferential statistical analysis. Based on the \\
results of hypothesis testing it is known that for minor hypotheses it \\
is known that all aspects tested, namely the communicator, message \\
and media aspects have a significant relationship with the behavior \\
of parents in providing sex education to adolescents, so in general \\
based on Maior hypothesis testing it can be said that the \\
dissemination activities information about sex education has a \\
significant relationship with the ability of parents to explain about
\end{tabular}


sex in their teenage children. From the results of this study it can be concluded that the dissemination of information about sex education through counseling activities to parents is very effective in explaining about sex in young children.

Keyword: Information dissemination, Communication,Ssex education, Teenagers

Kata kunci: diseminasi informasi, komunikasi, pendidikan seks, remaja

\begin{abstract}
ABSTRAK
Penelitian ini bertujuan untuk mengetahui hubungan penyebaran informasi pendidikan seks dengan perilaku orang tua dalam menjelaskan tentang seks pada anak usia remaja. Adapun variabel dalam penelitian ini terdiri dari variable bebas yakni penyebaran informasi yang meliputi aspek komunikator, pesan dan media serta variabel terikatnya yaitu perilaku orang tua dalam menjelaskan pendidikan seks. Lokasi penelitian dilakukan di Desa Banjurpassar yang merupakan salah satu wilayah desa di wilayah pesisir Kabupaten Kebumen. Pendekatan yang digunakan dalam penelitian ini menggunakan pendekatan kuantitatif dengan jenis penelitian korelasi. Populasi dalam penelitian adalah orang tua yang menjadi peserta penyuluhan tentang Pendidikan seks yang diberikan Dinas Kesehatan Kab, Kebumen. Sedangkan untuk tenik pengambilan sampelnya menggunakan teknik simple random sampling. Untuk teknik pengumpulan datanya dilakukan melalui angket, wawancara, observasi serta melalui studi kepustakaan. Adapun untuk analisis datanya menggunakan analisis statistika deskriptif dan analisis statistika inferensial. Berdasarkan hasil pengujian hipotesis diketahui bahwa untuk hipotesis minor diketahui seluruh aspek yang diuji yakni aspek komunikator, pesan dan media memiliki hubungan yang signifikan dengan perilaku orang tua dalam melakukan memberikan pendidikan seks pada anak remaja, sehingga secara umum berdasarkan pengujian hipotesis maior dapat dikatakan bahwa kegiatan penyebaran informasi tentang pendidikan seks memiliki hubungan yang signifikan dengan kemampuan orang tua dalam menjelaskan tentang seks pada anak usia remaja mereka. Dari hasil penelitian ini dapat disimpulkan bahwa penyebaran informasi tentang pendidikan seks melalui kegiatan penyuluhan pada orang tua sangat efektif dalam menjelaskan tentang seks pada anak usia remaja.
\end{abstract}

(C) 2020 NJILS. All rights reserved

\section{A. PENDAhUluan}

Pertumbuhan manusia tidak terlepas dari beberapa fase penting dalam hidupnya, salah satunya adalah fase remaja. Remaja adalah merupakan fase peralihan antara anak-anak menuju dewasa yang mana pada masa ini banyak sekali perubahan yang terjadi secara signifikan baik dari sikap, psikologis, pola pikir, serta perilakunya sehari-sehari. Pada masa remaja ini fungsifungsi hormonal dalam tubuh remaja juga mulai berkembang dan pada umumnya perkembangan fisik pada fase remaja lebih cepat berjalan daripada perkembangan mental atau psikologisnya. 
Remaja lebih dikenal sebagai sosok dengan rasa ingin tahu yang sangat besar. Banyak minat yang berkembang pada masa remaja, seperti minat sosial dan minat seputar masalah seks. Terlebih di zaman yang semakin maju saat ini atau yang lebih dikenal dengan era globalisasi, seks dan pergaulan bebas di kalangan remaja Indonesia saat ini bukanlah suatu hal yang baru lagi, sebuah kenyataan yang memprihatinkan.

Kemudian pada masa remaja ini juga merupakan masa yang sangat konsumtif terhadap berbagai informasi. Informasi apapun yang diterima seringkali langsung ditelan mentah-mentah tanpa mengetahui apakah informasi tersebut baik untuk dirinya atau tidak. Apalagi generasi milenial saat ini sangat mudah sekali mencari informasi apapun yang mereka butuhkan menggunakan teknologi yang sudah semakin canggih dan berkembang ini. Berkaitan dengan hal ini Rinta (2015) mengatakan pada dewasa ini informasi tentang masalah seksual sudah seharusnya mulai diberikan untuk menghindari para remaja mencari informasi sendiri dari teman atau sumber lain yang tidak jelas atau bahkan keliru sama sekali. Oleh karena itu peran orangtua sangat diperlukan untuk mengawasi dan mengontrol semua kegiatan anak-anak remaja mereka, serta mengetahui informasi apa saja yang setiap harinya dikonsumsi oleh anak-anak mereka, apalagi orangtua merupakan fondasi utama bagi pertumbuhan anak-anaknya. Selain itu juga saat ini sudah banyak orang tua yang terbiasa menggunakan gadget dan internet, sehingga para orangtua juga tidak akan tertinggal informasi terbaru yang sedang tranding di seluruh dunia. Hal ini tidak menutup kemungkinan bahwa orangtua sekarang sudah mengetahui tentang sex eduation atau pendidikan seks.

Pendidikan seks atau biasa dikenal dengan sex education dulunya dianggap sangat tabu oleh hampir semua masyarakat Indonesia, terutama di daerah pedesaan. Hal ini juga dibenarkan Mukti (2016) yang mengatakan masih adanya perspepsi masyarakat mengenai pendidikan seks yang masih menganggap tabu untuk dibicarakan Bersama anak-anaknya. Hal ini karena adanya anggapan pendidikan seks dianggap mengandung pembahasan-pembahasan yang tidak seharusnya disebar luaskan secara umum. Pendapat yang tidak jauh berbeda juga diutarakan Kristanti (2018) yang menyebutkan bahwa :

"Seksualitas masih merupakah hal yang tabu bagi masyarakat Indonesia, sehingga kita kerapkali tidak mau membahasnya namun tetap melakukannya. Adapun mengenai hal ini dikarenakan dikarenakan masih minimnya pihak-pihak yang menyebar luaskan informasi tentang pendidikan seks kepada masyarakat, sehingga masih banyak masyarakat yang tidak mengerti betapa pentingnya pendidikan seks sejak dini." 
Masyarakat Indonesia yang hidup di ibu kota atau tidak jauh dari ibu kota mungkin sudah tidak asing dengan apa itu pendidikan seks, tapi untuk masyarakat yang hidup jauh dari ibu kota tentu masih sangat asing dengan pendidikan seks. Salah satu wilayah yang masih jauh dari pengetahuan tentang pendidikan seks adalah daerah pesisir selatan pulau jawa, seperti yang terlihat di daerah pesisir Kebumen, Jawa Tengah. Untuk wilayah Kebumen sendiri sosialisasi tentang pentingnya pendidikan seks masih jarang sekali dilakukan, terutama daerah pesisirnya. Kendala dari proses sosialisasi ini antara lain adalah warga masyarakatnya yang masih menganggap tabu tentang pendidikan seks ini. Sebagian besar dari mereka menganggap bahwa jika anak-anak dan remaja diberi pelajaran tentang seks, mereka nanti akan menjadi penasaran dan malah ingin mencoba.

Sebagian besar masyarakat di wilayah pesisir Kebumen masih menganggap tabu perihal pemberian pendidikan seks kepada remaja. Selain itu juga masih banyak orangtua yang belum tahu pentingnya pendidikan seks diberikan pada anak-anak mereka yang sudah masuk usia remaja. Hal senada juga dikemukakan Yusnita (2018) yang merujuk pada hasil survey yang dilakukan Komnas Perlindungan Anak (KPAI) dan Kementerian Kesehatan yang menyebutkan bahwa sebanyak 62,7\% remaja di Indonesia pernah melakukan hubungan seks di luar nikah. Melalui data tersebut menggambarkan bahwa perilaku seks bebas dikalangan anak-anak remaja sangat menghawatirkan. Adapun mengenai banyaknya orangtua yang belum memiliki pengetahjuan yang memadai dalam memberikan pendidikan seks kepada anak-anaknya menurut Erni (2013) disebabkan berbagai faktor seperti rendanya Pendidikan orangtua serta faktor ekonomi yang menyebabkan orangtua tidak memiliki banyak waktu untuk bertemu anakanaknya apalagi membicarakan masalah pendidikan seks.

Oleh karena demikian memperhatikan kondisi seperti ini beberapa wilayah di pesisir pantai Kebumen sudah mulai mendapatkan sosialisasi mengenai pentingnya pendidikan seks kepada remaja. Dinas Kesehatan Kabupaten Kebumen bekerjasama dengan puskesmaspuskesmas di setiap kecamatan mengadakan sosialisasi keliling ke beberasa desa di wilayah pesisir Kebumen. Salah satunya adalah di Desa Banjurpasar, Kecamatan Buluspesantren, Kabupaten Kebumen, Jawa Tengah. Dalam pelaksanaannya Dinas Kesehatan, Puskesmas

Kecamatan Buluspesantren serta PKK Desa Banjurpasar melakukan penyuluhan tentang Pendidikan seks bagi remaja dengan sasaran adalah para orangtua khususnya ibu-ibu yang 
memiliki anak remaja. Adapun dipilihnya para orangtua ini mengingat peran orangtua sangat penting dalam memberikan Pendidikan seks agar anak-anak mereka mendapat informasi yang benar dan sehat, bahkan lembaga internasional seperti UNICEF, WHO dan UNAIDS telah membuat buku panduan pendidikan seksual komprehensif bagi orangtua dan guru di sekolah.

Melalui kegiatan penyuluhan yang diselenggarakan oleh Dinas kesehatan Kabupaten Kebumen, Puskesmas serta Ibu-ibu PKK, diharapkan dapat memberikan bekal pengetahuan dan pemahaman bagi para orangtua khususnya ibu-ibu yang memiliki anak remaja dalam menjelaskan tentang Pendidikan seks. Apalagi saat ini dengan adanya perkembangan teknologi informasi anak-anak sangat mudah mengakses berbagai sumber informasi khususnya melalui internet dan media sosial lainnya, sehingga perlu adanya pendampingan dari para orangtua. Selain itu juga melalui pendidikan seks para orangtua dapat menjelaskan pada anak-anak mereka mengenai berbagai hal tentang pendidikan seks seperti pentingnya menjaga dan merawat organ intim agar tetap sehat dan terhindar dari penyakit-penyakit yang berbahaya serta perlunya mengetahui resiko pertemanan terlalu dekat antara pria dan wanita kalua tidak bias menjaga diri bisa berakhir dengan hubungan seksual. Oleh karena demikian berangkat dari hal tersebut, penulis tertarik untuk mengangkat kegiatan penyebaran informasi tentang pendidiksan seks kaitannya dengan kemampuan para orangtua dalam menjelaskan Pendidikan seks pada anakanak mereka.

Dalam mengkaji penelitian tersebut di atas penulis berangkat dari beberapa penelitian terdahulu yaitu, pertama, penelitian yang dilakukan dilakukan oleh Santiana Nur Jannah dari Fakultas Ilmu Pendidikan, Universitas Negeri Yogyakarta dengan judul "Persepsi Orang Tua dan Guru tenteng Perkembangan dan Pendidikan Seksual Anak Autistik Usia Remaja di SLB Autis Citra Mulia Mandiri Yogyakarta”. Penelitian ini ditulis pada tahun 2016, dengan menggunakan metode penelitian kualitatif deskriptif. Kesimpulan dari penelitian ini adalah perkembangan seksual anak autistik usia remaja sama seperti anak pada umumnya hanya saja beberapa anak autistik mengalami perkembangan yang lebih cepat maupun lebih lambat. Perbedaannya hanya pada cara mengekspresikannya, anak autistik cenderung menyalurkan seksualnya kepada diri sendiri tetapi juga kepada orang lain. Kedua, penelitian yang dilakukan oleh Woro Dyah Anggraeni dari Universitas Diponegoro dengan judul "Komunikasi untuk Pendidikan Seks pada Anak Usia Dini”. penelitian ini ditulis pada tahun 2014. Metode penelitian yang digunakan dalam penelitian ini adalah metode penelitian fenomenologi kualitatif. Kesimpulan dari 
penelitian ini adalah peran pengasuhan memberikan kesempatan bagi ibu untuk memiliki frekuensi yang lebih dalam berinteraksi dengan anak, sehingga memberikan peluang adanya kedekatan di antara mereka. Kedekatan sangat diperlukan terutama dalam membahas topik yang bersifat pribadi seperti seksualitas. Ketiga, penelitian yang dilakukan oleh Nurlaila Novi Istiqomah dari Fakultas Tarbiyah dan Ilmu Keguruan Institut Agama Islam Negeri (IAIN) Metro dengan judul "Peran Orang Tua dalam Pendidikan Seks bagi Remaja menurut Perspektif Islam". Penelitian ini ditulis pada tahun 2017. Metode yang dilakukan dalam penelitian ini adalah metode penelitian kualitatif deskriptif. Kesimpulan dari penelitian ini adalah Peran orangtua dalam pendidikan seks bagi remaja menurut prespektif Islam (studi di desa Tanjung Qencono Kecamatan Way Bungur Kabupaten Lampung Timur) tidak mudah dan merupakan tugas yang berat. Keempat, penelitian yang keempat dilakukan oleh Peni Rahma Anindita dari Fakultas Ilmu Kesehaatan, Universitas 'Aisyiyah dengan judul "Pengaruh Penyuluhan Pendidikan Seksual Dini terhadap Tingkat Pengetahuan pada Ibu di TK Aba Wirobrajan I dan II Yogyakarta”. Penelitian ini ditulis pada tahun 2017. Metode yang digunakan dalam penelitian ini adalah metode preexperimental. Kesimpulan dari penelitian ini adalah penyuluhan memiliki pengaruh terhadap tingkat pengetahuan ibu tentang pendidikan seksual anak.

Berdasarkan keempat penelitian tersebut di atas, apabila dikaitkan dengan topik yang dibahas penulis yakni tentang penyebaran informasi tentang pendidikan seks nampaknya belum dibahas dalam penelitian mereka, sehingga jika dilihat dari unsur novelty atau kebaruan penelitian sudah memenuhi persyaratan untuk menjadi topik penelitian. Sedangkan mengenai tujuan dari penelitian ini yaitu untuk mengetahui keterkaitan atau hubungan antara penyebaran informasi yang meliputi unsur komunikator, pesan dan media dengan kemampuan para orangtua dalam menjelaskan tentang pendidikan seks pada anak-anak remaja mereka.

\section{B. TINJAUAN PUSTAKA}

Kata penyebaran merupakan sinonim dari diseminasi. Jasi penyebaran informasi sinonim dengan diseminasi informasi. Adapun mengenai pengertian diseminasi informasi menurut Ahmad dalam Nurazizah (2018) yang mengatakan bahwa diseminasi informasi adalah suatu kegiatan penyebaran informasi, terencana, diarahkan, dan dikelola untuk ditujukkan kepada pengguna atau individu agar mereka memperoleh informasi. Sedangkan menurut Andries (2012) menyatakan bahwa diseminasi informasi adalah suatu kegiatan yang ditujukan kepada kelompok 
target atau individu agar mereka memperoleh informasi, sehingga timbul kesadaran, menerima, dan akhirnya memanfaatkan informasi tersebut.

Proses penyebaran informasi dilakukan kepada suatu kelompok yang menjadi target untuk diubah secara pemikiran dan sikap sesuai dengan tujuan suatu lembaga. Oleh karena itu proses diseminasi tidak dilakukan secara spontan tetapi dilakukan dengan strategi dan pernecanaan yang matang. Kegiatan diseminasi informasi mungkin dapat berbentuk sosialisasi, penyuluhan, pelatihan, seminar ataupun diskusi. Diseminasi melalui penyuluhan biasanya dilakukan untuk informasi yang berisi suatu topik yang berupa praktek. Masyarakat yang menerima informasi tersebut diharapkan dapat menerapkan apa yang telah disampaikan dalam kehidupan, baik kehidupan sehari-hari maupun perkerjaan tergantung pada topik.

Dengan adanya diseminasi, informasi dapat menyebar dengan cepat dan diketahui publik. Kegiatan diseminasi informasi memudahkan lembaga baik pemerintah maupun non pemerintah untuk menyebarkan informasi atas suatu topik untuk mempengaruhi masyarakat dalam segi pemikiran maupun perilaku. Berkaitan dengan konsep diseminasi Ordonez dan Serrat (2017), diseminasi adalah proses interaksi dalam mengkomunikasikan pengetahuan untuk target khalayak sehingga bisa digunakan untuk mengarah pada perubahan. Diseminasi dipengaruhi oleh lima hal saling berhubungan, yaitu source (komunikator), content (pesan), context (konteks), medium (media) dan user (penerima).

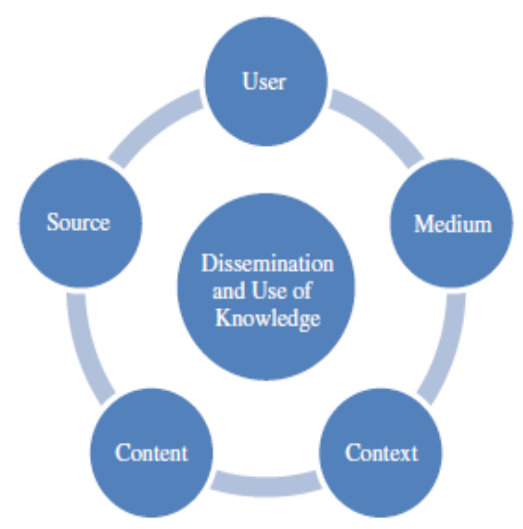

Gambar 1 Disemination and Use of Knowledge Sumber : Muriel Ordonez dan Olvier Serrat, 2017

Berdasarkan gambar tersebut di atas, dapat dijelaskan bahwa diseminasi informasi terdiri dari komponen atau unsur-sunsur sebagai berikut: 1) Komunikator (source). Sumber dalam diseminasi informasi yaitu pihak yang menjadi penyedia informasi. Dalam proses diseminasi 
informasi, sumber harus jelas dapat dipercaya dan memiliki kredibilitas karena informasi yang disebarkan harus tervalidasi kebenarannya dan keluar dari sumber yang memang kompeten untuk menyampaikan informasi tersebut. Hal senada juga dikemukakan Cangara (2018) yang mengatakan bahwa komunikator merupakan kunci dari suatu kegiatan komunikasi atau dengan kata lain berhasil tidaknya proses komunikasi sangat ditentuukan oleh faktor komunikator atau sumber; 2) Pesan (content). Unsur kedua dalam diseminasi informasi adalah pesan. Adapun mengenai pesan adalah segala sesuatu yang disampaikan oleh seseorang dalam bentuk simbol yang dipersepsi dan diterima oleh khalayak dalam serangkaian makna; 3) Konteks (context) dalam konsep komunikasi diartikan sebagai faktor diluar orang yang berkomunikasi, yang terdiri dari aspek fisik, aspek psikologi, aspek sosial, dan aspek waktu (Mulyana 2015). Adapun indikator yang paling umum untuk mengklasifikasikan komunikasi berdasarkan konteksnya atau tingkatnya adalah jumlah peserta yang terlibat dalam komunikasi; 4) Media (medium) yakni segala sesuatu yang berupa sarana dan saluran yang mendukung untuk menyempaikan pesan serta; 5) Penerima (user) dalam konteks komunikasi istilah penerima disebut juga komunikan, audience atau user, yakni orang baik individu maupun kelompok yang menjadi target atau sasaran komunikator untuk menyampaikan pesan komunikasi.

Ada berbagai pengertian yang menjelaskan tentang pendidikan seks salah satunya yang dikemukakan Djiwandono dan Wuryani (2016) yang mengatakan bahwa pendidikan seks (sex education) merupakan pendidikan mengenai tingkah laku yang baik yang menjunjung tinggi nilai-nilai kemasyarakatan, serta membantu seseorang dalam menghadapi persoalan hidup yang bekaitan dengan seksualitas yang timbul dalam bentuk-bentuk tertentu. Sedangkan Surtiretna (2014) mengatakan pendidikan seks adalah sebuah upaya untuk memberikan pengetahuan tentang perubahan biologis, psikologis, dan psikososial sebagai akibat pertumbuhan dan perkembangan kejiwaan manusia, atau dengan kata pendidikan pendidikan seks pada hakikatnya merupakan usaha untuk membekali pengetahuan tentang fungsi organ reproduksi dengan menanamkan moral, etika serta agama agar tidak terjadi penyalahgunaan organ reproduksi tersebut.

Dalam Pendidikan seks terkandung nilai-nilai yang sangat luas dimana nilai-nilai tersebut yang akan menjadi pijakan dalam perumusan tujuan pendidikan seks ini. Selain itu juga nilainilai dalam pendidikan seks menjadi sangat penting karena menyangkut moralitas sosial yang menjadi tolok ukur sebuah kecakapan dalam masyarakat. Selain itu juga pendidikan seks sangat 
penting diberikan sejak dini pada anak-anak. Apalagi saat ini kehadiran teknologi seperti gadget seakan-akan telah mengambil peran orang tua. Saat ini kita sulit untuk menghalang-halangi anak-anak menggunakan teknologi dan setiap orang memiliki kesempatan untuk mengakses sumber informasi termasuk informasi yang kurang baik yang tidak patut dilihat oleh anak-anak seperti informasi tentang kekerasan, pornografi, dll. Oleh karena itu peran orang tua dalam memberikan bimbingan pada anak-anak mereka menjadi sangat penting.

Kemudian mengenai pengertian anak remaja yang dimaksudkan adalah kelompok anak remaja yang akan memasuki usia dewasa. Pada masa ini rentang ini mereka tidak mempunyai tempat yang jelas karena tidak termasuk golongan anak tetapi tidak juga golongan dewasa atau tua. Hal senada juga dikemukakan Sri Rumini dan Siti Sundari (2015) yang menyebutkan bahwa masa remaja adalah peralihan dari masa dari masa anak dengan masa dewasa yang mengalami perkembangan semua aspek untuk memasuki masa dewasa. Sebagai masa peralihan dari masa anak menuju dewasa, ada beberapa perubahan yang tampak pada kelompok remaja ini seperti perubahan secara fisik, biologis, mental, emosional serta psikososial dimana kesemua aspek tersebut akan mempengaruhi kehidupan pribadi, lingkungan keluarga maupun lingkungan masyarakat. Berkaitan dengan hal ini Rinawati dan Nugraheni (2019) menyatakan bahwa adanya hubungan orangtua dan anak-anaknya yang positif selama masa anak-anak akan berpengaruh terhadap perkembangan positif sepanjang hidup anak. Namun demikian sampai saat ini dalam pendidikan formal di Indonesia nampaknya sekolah belum secara khusus memasukan pendidikan seks dalam kurikulum. Oleh karena itu perlu adanya keterlibatan orangtua dalam menjelaskan pendidikan seks yang benar agar anak-anak mereka memahami tentang seks secara tepat.

Ada beberapa hal yang harus dipersiapkan serta disampaikan dalam melakukan pendidikan seks seperti mencari waktu yang tepat untuk membicaran pendidikan seks misalnya pada saat berbelanja bersama atau perjalan pulang di mobil. Selain itu juga dalam menjelaskan pendidikan seks orangtua harus menjadikannya moment ini sebagai ajang diskusi dan bukan untuk menghakimi anak. Sedangkan berkaitan dengan topik yang dibicarakan dalam pendidikan seks mulai dari cara mengenali anggota tubuh, memelihara kesehatan tubuh, cara bergaul dan memilih teman, cara berpacaran yang sehat serta membahas tentang kehamilan dan penyakitpenyakit menular yang berkaitan dengan hubungan intim yang tidak sehat.

Hadirnya orangtua dalam pendidikan seks pada anak-anak mereka sudah saatnya menjadi program setiap orangtua. Apalagi saat ini dengan keterbukaan dalam mengakses informasi 
melalui media internet mapun media sosial tanpa dan pendampingan dan arahan dari orangtua bisa menimbulkan efek yang tidak diharapkan seperti terjerumus dalam pergaulan bebas, pornografi, kekerasan, dll.

\section{METODE PENELITIAN}

Pendekatan yang yang digunakan dalam penelitian ini menggunakan pendekatan kuatitatif dengan jenis penelitian korelasional. Adapun penelitian korelasional adalah penelitian yang bertujuan untuk melihat hubungan antarvariabel Suharsaputra (2012). Analisis korelasional biasanya digunakan unuk mengetahui ada atau tidak adanya hubungan antarvariabel. Sedangkan yang menjadi populasi dalam penelitian ini adalah para orangtua yang telah mengikuti kegiatan penyuluhan tentang pendidikan seks yang diselenggarakan di Desa Banjurpasar, Kecamatan Buluspesantren Kabupaten Kebumen. Untuk teknik pengambilan sampelnya menggunakan random acak sederhana (simple random sampling). Sedangkan untuk menghitung jumlah sampelnya digunakan rumus Slovin dengan rumus sebagai berikut :

$$
\mathrm{n}=\frac{N}{1+\mathbb{N} \alpha^{2}}
$$

Keterangan :

- N : Populasi

- $\mathrm{n}$ : Ukuran Sampel

- $\alpha$ : tingkat kesa;ahan yaitu sebanyak $10 \%$ atau dengan tingkat kepercayaan $90 \%$ maka tingkat Sumber : Slovin, 2005, 82)

Berdasarkan hasil perhitungan dengan menggunakan rumus diatas maka diperoleh jumal sampel sebanyak 65 orang.

Kemudian teknik pengumpulan data yang dilakukan dalam penelitian ini dilakukan melalui angket, observasi, wawancara serta melalui studi kepustakaan. Untuk analisis data penelitiannya dilakukan melalui 1). analisis statistika deskriptif yakni dengan cara menyajikan data penelitian dalam bentuk tabel maupun diagram untuk selanjutnya dideskripsikan dan dianalisis, 2) analisis statistika inferensial atau induktif yaitu analisis data yang digunakan untuk melakukan pengujian hipotesis dalam penelitian ini. 


\section{HASIL DAN PEMBAHASAN}

Dalam penelitian ini ada 33 item pertanyaan yang diajukan pada responden yang meliputi 4 pertanyaan mengenai identitas responden dan sebanyak 29 pertanyaan berkaitan dengan data penelitian. Dari hasil pengolahan data dapat dikemukakan hasil sebagai berikut.

Apabila dilihat dari data responden diketahui bahwa pada umumnya responden yang mengikuti kegiatan pelatihan berjenis kelamin perempuan serta sisanya sebanyak 6 orang lagi atau sekitar 9\% berjenis kelamin laki-laki. Mengenai banyaknya responden yang berjenis kelamin perempuan dalam penelitian ini dikarenakan penelitian ini berkaitan dengan pendidikan seks maka kaum ibu merasayang lebih tepat untuk mengikuti kegiatan tersebut. Selain itu juga kegiatan ini bisanya berbarengan dengan acara lain yang diselenggarakan ibu-ibu PKK. Adapun adanya responden pria yang mengikuti kegiatan ini menurut hasil observasi yang penulis lakukan salah satunya karena istrinya tidak bisa datang serta kebetulan responden tersebut menjadi aparat desa tersebut, sehingga pada saat kegiatan mereka ikut sebagai peserta. Untuk lebih jelasnya mengenai data tentang jenis kelamin responden dapat dilihat pada gambar di bawah ini :

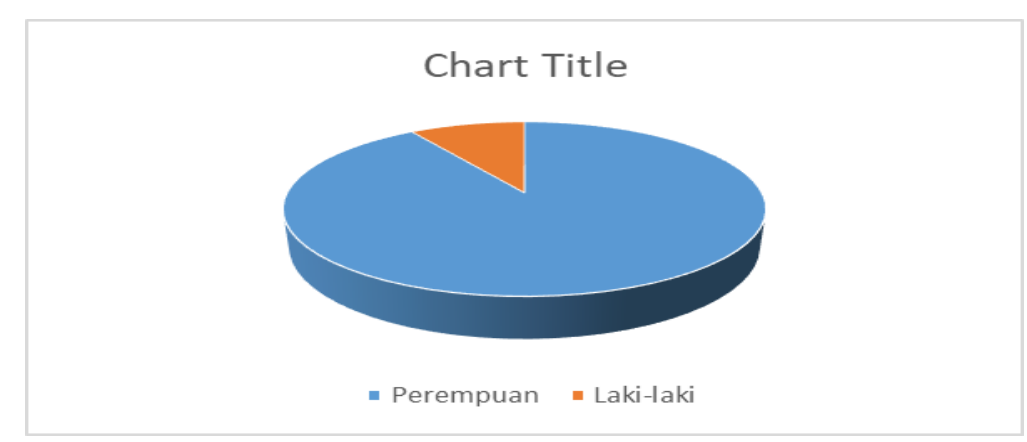

Gambar 2 Jenis Kelamin Responden Sumber : Data penelitian, 2019.

Kemudian dilihat dari usia responden sebanyak 27 orang berusia pada rentang usia 41-45 tahun, sebanyak 18 orang berusia pada rentang usia 46-60, sebanyak 12 orang berada pada rentang usia 36-40, serta sebanyak masing-masing 4 responden berada pada rentang usia 30-35 dan rentang usia lebih dari 50 tahun. 


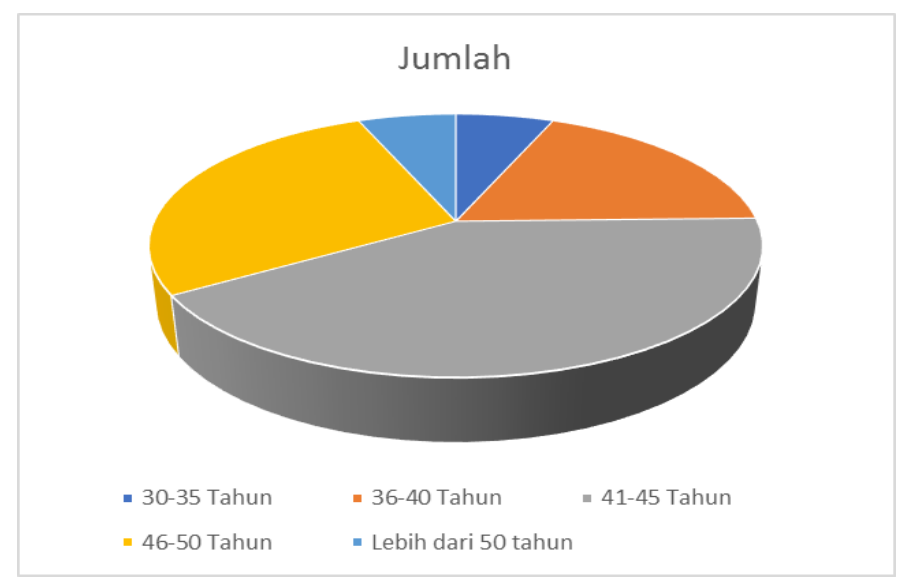

Gambar 3 Usia Responden

Sumber : Data penelitian, 2019

Sedangkan dilihat dari jumlah anak remaja yang dimiliki responden sebagian besar responden atau sekitar $83 \%$ hanya memiliki anak sebanyak 1 orang serta sisanya responden memiliki anak remaja sebanyak 2 sampai 3 orang. Namun yang menarik dari data responden ini jumlah anak yang dimiliki masyarakat Desa Banjurpasar tidak lebih dari 3 orang. Hal ini menggambar program keluarga berencana di wilayah ini cukup berhasil serta kesadaran masyarakat tentang memiliki keluarga kecil dan sejahtera mulai tumbuh pada masyarakat ini.

Kemudian mengenai data penelitian yang berkaitan dengan aspek komunikator diketahui bahwa sebagian besar responden menyatakan pesan yang disampaikan komunikator mudah dipahami, komunikator selalu menjawab pertanyaan yang diajukan responden, memberikan argument yang jelas dengan memberikan ilustrasi, serta sebagian besar responden juga mengatakan ingin mengetahui lebih jauh tentang pendidikan seks. Sedangkan untuk aspek pesannya sebagian besar responden menyatakan pesan yang disampaikan tentang pendidikan sangat jelas, dapat menambah pengetahuan, responden lebih mengerti tentang pendidikan seks, responden bias lebih memahami dan menyadari pentingnya pendidikan seks. Selain itu juga berkaitan dengan aspek pesan ini telah memunculkan rasa ingin tahu responden dan lebih menyakinkan reponden untuk memberikan pendidikan seks pada anak-anak mereka.

Untuk aspek media diketahui bahwa menurut sebagian responden media yang digunakan untuk penyebaran informasi tentang pendidikan seks telah sesuai, menarik serta mewakili informasi yang disampaikan serta mampu membantu dalam memahami pesan yang disampaikan. Berkaitan dengan media mwnurut Aqib (2013) mengartikan media adalah segala sesuatu yang dapat digunakan untuk menyalurkan pesan, merangsang pikiran, perasaan, perhatian, kemauan 
siswa/peserta sehingga dapat mendorong proses belajar. Pengajaran dengan menggunakan media tidak hanya menggunakan kata-kata (simbol verbal) tetapi simbol non verbal maupun alat tertentu.

Mengenai variabel yang berkaitan dengan perilaku responden diketahui bahwa sebagian besar responden menyadari bahwa bahwa pendidikan seks penting untuk diberikan kepada remaja sejak dini, responden memperhatikan perkem-bangan seksual remaja serta responden akan melakukan tindakan untuk mengatasi jika ada ada hal yang tidak biasa pada anak mereka, serta responden mulai memberikan pendidikan seks pada anak-anak mereka dalam berbagai kesempatan dengan cara diskusi atau menjelaskan peristiwa dikaitkan dengan pendidikan seks.

Kemudian mengenai hasil pengujian hipotesis berdasarkan analisis statistic inferensial dapat dikemukakan hasil sebegai berikut :

$\mathrm{H}_{\mathrm{o}}$ : Tidak ada hubungan antara aspek komunikator dengan perillaku orangtua dalam menjelaskan pendidikan seks.

$\mathrm{H}_{1}$ : Terdapat hubungan antara aspek komunikator dengan perillaku orangtua dalam menjelaskan pendidikan seks.

Dengan menggunakan tingkat kepercayaan $95 \%$ dan $\alpha=0.05$, berdasarkan perhitungan dengan menggunakan spearman rank order diperoleh koefisien korelasi sebesar 0.756 . Sedangkan untuk mengetahui kekuatan hubungan korelasinya, peneliti menggunakan pedoman Guildford dalam Rahmat (2019). Adapun berdasarkan pedoman tersebut koefisien korelasi 0.756 termasuk kategori hubungan kuat.

Selanjutnya untuk membuktikan hipotesis yang peneliti ajukan caranya dengan membandingkan antara sign test dengan tingkat kesalahan $(\alpha=0.05)$. Adapun ketentuannya adalah sebagai berikut : jika sign. Test $>$ tingkat kesalahan $(\alpha=0.05)$, maka Ho diterima dan H1 ditolak, artinya tidak terdapat hubungan. Sedangkan jika sign. Test $<$ tingkat kesalahan $(\alpha=$ 0.05), maka Ho ditolak dan H1 diterima, artinya terdapat hubungan.

Berdasarkan hasil perhitungan di atas diketahui bahwa Jika sign. Test < tingkat kesalahan $(\alpha=0.05)$, artinya terdapat hubungan antara antara aspek komunikator dengan perillaku orangtua 
$\mathrm{H}_{\mathrm{o}}$ : Tidak ada hubungan antara aspek pesan dengan perillaku orangtua dalam menjelaskan pendidikan seks.

$\mathrm{H}_{1}$ : Terdapat hubungan antara aspek pesan dengan perillaku orangtua dalam menjelaskan pendidikan seks.

Dengan menggunakan tingkat kepercayaan $95 \%$ dan $\alpha=0.05$, berdasarkan perhitungan dengan menggunakan spearman rank order diperoleh koefisien korelasi sebesar 0.719 . Sedangkan untuk mengetahui kekuatan hubungan korelasinya, peneliti menggunakan pedoman Guildford dalam Rahmat (2019). Adapun berdasarkan pedoman tersebut koefisien korelasi 0.719 termasuk kategori hubungan kuat.

Selanjutnya untuk membuktikan hipotesis yang peneliti ajukan caranya dengan membandingkan antara sign tes dengan tingkat kesalahan $(\alpha=0.05)$. Adapun ketentuannya adalah sebagai berikut : jika sign. Test $>$ tingkat kesalahan $(\alpha=0.05)$, maka Ho diterima dan H1 ditolak, artinya tidak terdapat hubungan. Sedangkan jika sign. Test $<$ tingkat kesalahan $(\alpha=$ 0.05), maka Ho ditolak dan H1 diterima, artinya terdapat hubungan.

Berdasarkan hasil perhitungan di atas diketahui bahwa Jika sign. Test < tingkat kesalahan $(\alpha=0.05)$, artinya terdapat hubungan antara antara aspek pesan dengan perillaku orangtua.

$\mathrm{H}_{\mathrm{o}}$ : Tidak ada hubungan antara aspek media dengan perillaku orangtua dalam menjelaskan pendidikan seks.

$\mathrm{H}_{1}$ : Terdapat hubungan antara aspek media dengan perillaku orangtua dalam menjelaskan pendidikan seks.

Dengan menggunakan tingkat kepercayaan $95 \%$ dan $\alpha=0.05$, berdasarkan perhitungan dengan menggunakan spearman rank order diperoleh koefisien korelasi sebesar 0.784 . Sedangkan untuk mengetahui kekuatan hubungan korelasinya, peneliti menggunakan pedoman Guildford dalam Rahmat (2019). Adapun berdasarkan pedoman tersebut koefisien korelasi 0.784 termasuk kategori hubungan kuat.

Selanjutnya untuk membuktikan hipotesis yang peneliti ajukan caranya dengan membandingkan antara sign tes dengan tingkat kesalahan. Adapun ketentuannya adalah sebagai berikut : jika sign. Test > tingkat kesalahan $(\alpha=0.05)$, maka Ho diterima dan H1 ditolak, artinya tidak terdapat hubungan. Sedangkan jika sign. Test $<$ tingkat kesalahan $(\alpha=0.05)$, maka Ho ditolak dan $\mathrm{H} 1$ diterima, artinya terdapat hubungan. 
Berdasarkan hasil perhitungan di atas diketahui bahwa Jika sign. Test < tingkat kesalahan $(\alpha=0.05)$, artinya terdapat hubungan antara antara aspek media dengan perilaku orangtua

$\mathrm{H}_{\mathrm{o}}$ : Tidak ada hubungan antara penyebaran informasi dengan perillaku orangtua dalam menjelaskan pendidikan seks.

$\mathrm{H}_{1}$ : Terdapat hubungan antara penyebaran informasi dengan perillaku orangtua dalam menjelaskan pendidikan seks.

Dengan menggunakan tingkat kepercayaan 95\% dan $\alpha=0.05$, berdasarkan perhitungan dengan menggunakan spearman rank order diperoleh koefisien korelasi sebesar 0.827 . Sedangkan untuk mengetahui kekuatan hubungan korelasinya, peneliti menggunakan pedoman Guildford dalam Rahmat (2019). Adapun berdasarkan pedoman Guildford koefisien korelasi 0.827 termasuk kategori hubungan kuat.

Selanjutnya untuk membuktikan hipotesis yang peneliti ajukan caranya dengan membandingkan antara sign tes dengan tingkat kesalahan. Adapun ketentuannya adalah sebagai berikut : jika sign. Test $>$ tingkat kesalahan $(\alpha=0.05)$, maka Ho diterima dan H1 ditolak, artinya tidak terdapat hubungan. Sedangkan jika sign. Test $<$ tingkat kesalahan $(\alpha=0.05)$, maka Ho ditolak dan H1 diterima, artinya terdapat hubungan.

Berdasarkan hasil perhitungan di atas diketahui bahwa Jika sign. Test < tingkat kesalahan $(\alpha=0.05)$, artinya terdapat hubungan antara antara penyebaran informasi dengan perillaku orangtua.

\section{E. KESIMPULAN DAN SARAN}

Dari hasil pengujian hipotesis maior dengan menggunakan uji statistik Spearman Rank Order, tingkat kesalahan $(\alpha=0.05)$, diketahui terdapat hubungan antara penyebaran informasi dengan perilaku orang tua dalam menjelaskan pendidikan seks. Sedangkan untuk pengujian hipotesis minor, dari tiga hipotesis yang diajukan semua hipotesis diterima yakni terdapat hubungan antara aspek komunikator, aspek pesan serta aspek media dengan perilaku orangtua dalam menjelaskan pendidikan seks dengan kategori hubungan kuat. Berdasarkan hasil penelitian ini menggambarkan bahwa penyebaran informasi pendidikan seks melalui kegiatan penyuluhan sangat efektif bagi orang tua dalam membeikan Pendidikan seks sedinni mungkin pada anak-anak remaja mereka. Oleh karena itu peneliti merekomendasikan sosialisasi pendidikan seks melalui penyuluhan pada orangtua khususnya orangtua yang memiliki anak- 
anak remaja perlu lebih ditingkatkan lagi dan diperluas lagi dengan melibatkan berbagai pihak seperti ibu-ibu PKK, tokoh masyarakat serta tokoh-tokoh agama. Selain itu juga perlu adanya penelitian lebih lanjut tentang pendidikan seks pada anak usia dini dan anak remaja dilihat dari aspek media komunikasi dan media sosial.

\section{DAFTAR PUSTAKA}

Andries 2012. Pertanian hijau, Diseminasi teknologi pertanian.: http://agronomi3000.blogspot.co.id/2012/05/diseminasi-teknologipertanian.html diakses 12 Mei 2016.

Djaffar (2017) Diseminasi Teknologi Informasi Pada Masyarakat Nelayan di Kabupaten Takalar dan Barru, Jurnal Penelitian Komunikasi Dan Opini Publik, $21 \quad$ (1) 73-87. https://media.neliti.com/media/publications/124253-ID-none.pdf

Djiwandono, and Wuryani. (2014). Pendidikan Seks Keluarga. Jakarta: PT. Indeks.

Erni (2013). Pendidikan Seks Pada remaja, Jurnal Health Quality, $3 \quad$ (2), 69-140. https://journal.uii.ac.id/intervensipsikologi/article/view/12653.

Harmsworth, S., and S. Turpin. (2014). "Creating an Effective Dissemination Strategy: An Expanded Interactive Workbook for Educational Development Projects.” TQEF National Co-Ordination Team, 1-33. http://www.innovations.ac.uk/btg/resources/publications/dissemination.pdf.

Kristianti (2018). "Dianggap Tabu, Ke Mana Remaja Harus Bertanya Soal Seks.” 2018. https://lifestyle.kompas.com/read/2018/09/04/181200620/dianggap-tabu-ke-mana-remaja-

Kusumajanti, M. P. dan Anjang, P.

(2018). Diseminasi Informasi Publik

Infor Oleh Humas Kementerian Kelautan Dan Perikanan RI Dalam Menumbuhkan Public Awareness, Jurnal Komunikasi, $\quad$ Media Dan $\quad$ Informasi, $\quad 7(3), \quad 116-126$. https://jurnal.kominfo.go.id/index.php/komunika/article/download/1630/992

Marsaid. (2015). Perlindungan Hukum Anak Pidana Dalam Perspektif Hukum Islam (Maqasid Asy-Syari'ah). Palembang: NoerFikri.

Mukti (2016). Pendidikan Seks Untuk Anak usia Dini Dalam Perspektif Islam, Jurnal Harkat : Media Komunikasi Islam Tentanmg Gender dan Anak, 12 (2), 89-98.

http://journal.uinjkt.ac.id/index.php/psga/article/view/7562

Nurazizah (2018) Peran Pustakawan Dalam Diseminasi Informasi Via Jurnal Elektronik Lokal

Dan Dampaknya Terhadap Kepustakawanan Pemustaka di UPT Perpustakaan Unsyiah. Skripsi. Program S1 Ilmu Perpustakaan Fak. Adab Dan Humaniora Universitas Islam negeri Araniry Banda Aceh.

https://repository.ar-raniry.ac.id/id/eprint/4796/1/Nurazizah.pdf.

Ordonez, M (2017). Disseminating Knowledge Products. Knowledge Solution, 871-878. https://digitalcommons.ilr.cornell.edu/intl/179/ 
Prihandoyo, W. B (2015). Efektivitas Diseminasi Informasi Pertanian Melalui Media Telpon

genggam Pada Petani Sayuran Di Kecamatan Pacet Kabuaten Cianjur, Thesis, Sekolah Pasca Sarjana IPB. https://repository.ipb.ac.id/handle/123456789/73028

Retnowati, E (2015) Studi Deskriptif Diseminasi Informasi Pesan Kebencanaan di Kelompok Masyarakat Kawasan Rawan Bencana Desa Umbulharjo Kecamatan Cangkringan Kabupaten Selman Daerah Istimewa Yogyakarta, Skripsi. Universitas Dipenogoro. Semarang. https://ejournal3.undip.ac.id/index.php/interaksi-online/article/view/7302.

Rinawati dan Nugraheni (2019) Metode Pendidikan Seks Usia Dini Di Indonesia, Jurnal Kesehatan Masyarakat Andalas (JKMA), 13(1) 20-27. http://jurnal.fkm.unand.ac.id/index.php/jkma/article/download/388/253.

Rinta (2015). Pendidikan Seksual Dalam Perilaku Seksual Positif Pada Remaja Dan Implementasinya Terhadap Ketahanan Psikologi remaja, Jurnal Ketahanan Nasional 21 (3), 163-174. https://www.journal.ugm.ac.id/jkn/article/view/15587/10401.

Rodiah, S., dkk (2018). Model Diseminasi Informasi Kesehatan Masyarakat di Kabupaten Bandung Barat, Jurnal Kajian Komunikasi 6 (2), 175-190. http://jurnal.unpad.ac.id/jkk/article/download/15388/8304.

Surtiretna, Nina. (2013). Bimbingan Seks Bagi Remaja. Bandung: Remaja Rosdakarya.

Kristianti (2018). "Dianggap Tabu, Ke Mana Remaja Harus Bertanya Soal Seks.” 2018. https://lifestyle.kompas.com/read/2018/09/04/181200620/dianggap-tabu-ke-mana-remaja-harus-bertanyasoal-seks. Tanggal akses 3 Mei 2020.

Yusnita, A. (2018). "Darurat Seks Bebas Pada Generasi Muda." 2018. https://www.kompasiana.com/ariyantiyusnita8217/5b02794bbde5752fda0f56c3/darurat-seks-bebas-padagenerasi-muda?page=all, Tanggal akses 3 Mei 2020. 
